\section{Effect of sidaguri and jatropha on tooth microhardness and tooth surface: An in vitro evaluation using CLSM}

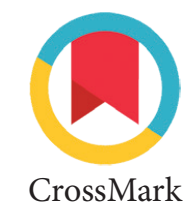

Maria Tanumihardja,${ }^{1 *}$ Nurhayaty Natsir, ${ }^{1}$ Indrya K. Mattulada, ${ }^{1}$ Hafsah Katu, ${ }^{1}$
Harun Achmad, ${ }^{2}$ Lukman Muslimin, ${ }^{3 *}$ Haerul Arsyad, ${ }^{4}$ Lukmanul H. Arma ${ }^{4}$

Abstract

Objective: The purpose of this study was to evaluate the effect of herbal alternatives, extract of sidaguri (sida rhombifolia) combine with extract of jatropha sap (jatropha curcas) application on microhardness and morphology of tooth surface.

Material and Methods: Twelve upper first premolar teeth were used in this study, prepared to Class I box cavities, and were then allocated into 4 groups $(n=3)$. Group 1-3 were treated groups, applied with combined extracts of a small dose $(5 \mathrm{mg})$, medium dose $(25 \mathrm{mg})$, and high dose $(50 \mathrm{mg})$, while group 4 was the control group. The cavities were restored with composite resin, immersed in artificial saliva, and stored at room temperature for 14 days. The fillings and extracts were removed and cleaned under running tap water. The teeth were cut in a vertical direction towards the apex, sectioned into $1 \mathrm{~mm}$ thickness, and evaluated using Laser Scanning Microscope (LSM), then were examined for microhardness test.

Results: All treated groups showed significantly lower microhardness than the control group. Tooth porosity was observed, and its extensiveness was affected by doses of extracts.

Conclusion: The application of herbal alternatives (extract of sidaguri and jatropha) lowered the microhardness of tooth structure and caused tooth porosities.
${ }^{1}$ Department of Conservative Dentistry and Endodontics, Faculty of Dentistry, Hasanuddin University, Makassar, Indonesia

${ }^{2}$ Department of Pediatric Dentistry, Faculty of Dentistry, Hasanuddin University, Makassar, Indonesia ${ }^{3}$ Sekolah Tinggi IImu Farmasi Makassar, Makassar, Indonesia ${ }^{4}$ Department of Mechanical Engineering, Faculty of Technical, Hasanuddin University, Makassar, Indonesia

${ }^{*}$ Correspondence to: Maria Tanumihardja,

Lukman Muslimin, Department of Endodontics, Faculty of Dentistry, Hasanuddin University, Makassar, Indonesia. Sekolah Tinggi IImu Farmasi Makassar, Makassar, Indonesia

mariatanumihardja@unhas.ac.id; lukman_m01@yahoo.co.id

Received: 1 June 2021

Revised: 10 June 2021

Accepted: 23 July 2021

Available Online: 1 August 2021

Keywords: Jatropha sap, Microhardness, Morphology, Sidaguri root, Tooth structure

Cite this Article: Tanumihardja M, Natsir N, Mattulada IK, Katu H, Achmad H, Muslimin L, Arsyad H, Arma LH. 2021. Effect of sidaguri and jatropha on tooth microhardness and tooth surface: An in vitro evaluation using CLSM. Journal of Dentomaxillofacial Science 6(2): 80-83. DOI: 10.15562/jdmfs.v6i2.1219

\section{Introduction}

Human teeth are the most challenging part of the body, composed of three mineralized tissues namely enamel, dentin and cementum, and other loose connective tissues, pulp, blood vessels, and nerve fibres. ${ }^{1}$ Enamel is the most mineralized part of the tooth, composed of $97 \%$ inorganic material as hydroxyapatite that makes enamel rigid, strong and brittle..$^{1-3}$ Enamel is supported by dentin, which forms the tooth's main structure and protects the soft tissues by covering the pulp. However, the enamel is soluble when exposed to an acid medium that decreases its hardness, and the solubility increases to the dentin-enamel junction (DEJ). Beneath the enamel is dentin, and dental pulp forms the pulpdentin complex that reacts to a stimulus, either biologic or non-biologic. Sensations in the pulpdentin are limited to pain reactions irrespective of the factor initiating the reaction. ${ }^{1}$

Dental pain has been considered the main reason to seek dental treatment or remedy from over counter products. However, some community practice certain herbs to manage the pain, either applied locally to the affected tooth or steeped in hot water. Some herbs commonly used to relieve the pain are ginger (zingiber officinale), jatropha (jatropha curcas), gambir (uncaria gambir), and sidaguri (sida rhombifolia). ${ }^{4-7}$ However, the mechanism behind it is still unclear.

Sidaguri, a family Malvaceae member, has been used for relieving toothache. An in vitro and animal model study showed its potency of antiinflammatory effect. ${ }^{8,9}$ At the same time, Jatropha curcas belongs to the Euphorbiaceae family that has been studied to relieve the pain by causing lysis of arterial blood in the pulp after 24 hours of application. ${ }^{10}$ A preliminary study showed that combining these herbs (jatropha and sidaguri) was promising as a good candidate for alternative devitalizing agents. ${ }^{5}$ However, the mechanism of how it works need to be examined.

To date, the advancement of microscope instruments is tremendous, which provide chances for the researchers to use the appropriate one. Concave laser scanning microscope (CLSM) is one of the microscopes usually used in dentistry as sample preparation is simple, and the samples can be repeatedly used. ${ }^{11,12}$ Previous studies using herbal extracts or drug had shown promising results through CLSM images. ${ }^{13}$ However, data on herbal alternatives like jatropha and sidaguri are scarce. 
In particular, their mechanism on tooth structure following their application despite their potency as a devitalizing agent has been reported. This study aimed to examine tooth structure's microhardness and images using CLSM following polyherbal application.

\section{Material and Methods Plant collection and extraction}

Roots of sidaguri were first identified and determined from their natural environment in Bone, South Sulawesi, Indonesia. The roots were then cut and separated from the trees, cleaned, dried, and grounded into powder, extracted using reflux method with ethanol $96 \%$. A rotary evaporator was used to evaporate and dry the extracts, then kept in a vacuum desiccator.

Jatropha sap was also collected from Bone district, South Sulawesi, freeze-dried by lyophilization (Buchi), kept in a vacuum desiccator till use.

\section{Paste preparation}

Extract of root of sidaguri and jatropha sap were mixed in equal proportion (25 $\mathrm{mg}$ ) 1:1, added with macrogol propylene glycol to form paste consistency, kept in a vacuum desiccator until they are used.

\section{Samples preparation}

This study has been approved by ethical clearance from Hasanuddin University (No. 0025/PL.09/ KEPK/FKG- RSGMUNHAS/2020).

Extracted upper first premolar teeth for orthodontic purpose were collected from the dental hospital. Combined extracts $25 \mathrm{mg}$ (equal weight) of root of sidaguri and jatropha sap was applied into Class I box cavities of 11 teeth. The cavities were restored with Fuji IX GIC capsules (GC Co, Japan), then allocated into 3 groups of 4 each, immersed in artificial saliva and stored at room temperature for 3 different periods. Group 1, samples were kept for 3 days; group 2, samples were kept for 5 days; and group 3, samples were kept for 7 days. After each period, the fillings and extracts were removed, and the cavities were cleaned under running tap water.

\section{Determination of microhardness}

The surface hardness of the cavities of each specimen was determined using a microhardness tester (ALPHA-MHT-1000Z). Three indentations were made with a Vicker's diamond indenter and recorded as 3 separate indentations each using a $500 \mathrm{~g}$ load and a 20- second dwell time. The indentations were placed. The length of the two diagonals was measured and then calculated the microhardness value.

\section{Determination of tooth surface}

The teeth were separated from the roots, then horizontally sectioned with low-speed diamond disc towards the cavities. The specimens were horizontally embedded into auto polymerizing acrylic resin, leaving the dentin exposed to facilitate further preparation. The mounted specimens were manually polished with a series of ascending grades of carbide abrasive papers $(1200,1500,2000$, and 3000 grit) and cleaned with an ultrasonic cleaner. Microhardness and images of treated samples were examined using CLSM (Olympus Lext OLS4100).

\section{Results}

The effects of root of sidaguri and jatropha sap on the tooth surface and microhardness of premolar teeth were studied and compared to untreated (control). Results obtained from the evaluation of tooth microhardness are fully explained in table 1 and table 2.

The decrease of microhardness of tooth structure was significantly different among the groups and control group. Numerically, the tooth hardness decreased in relevance to the time, although no difference was observed in samples of the control group and 3 days treated group. A similar hardness of the tooth structures was noted around the cavities either in the control sample or in treated samples.

Decrease of microhardness of tooth structure was significantly different between day 3 and day 7 $(\mathrm{p}<0.012)$; day 5 and control; day 7 and control after combined extract application. These results showed that the longer the time of combined extract kept

Table 1 Mean microhardness of tooth structure after combined extracts application

\begin{tabular}{lcccc}
\hline Groups & N & Mean \pm SD & Normality test* & Comparative test** $^{*}$ \\
\hline Day 3 & 3 & $26.56 \pm 1.72$ & $0.448^{*}$ & \\
Day 5 & 3 & $24.38 \pm 0.51$ & $0.785^{*}$ & $0.004^{* *}$ \\
Day 7 & 3 & $21.94 \pm 2.23$ & $0.592^{*}$ & \\
Control & 2 & $28.15 \pm 0.15$ & $1.000^{*}$ & \\
\hline
\end{tabular}

${ }^{*}$ Shapirowilk; level of significance $\mathrm{p}>0.05 ; \mathrm{Cl} 95 \%$

** One-way Anova; level of significance $\mathrm{p}<0.05 ; \mathrm{Cl} 95 \%$ 


\begin{tabular}{lccc} 
Table 2 & \multicolumn{3}{c}{$\begin{array}{l}\text { Continued difference test following combined extracts } \\
\text { application }\end{array}$} \\
\hline Groups & Comparison (j) & Mean difference (i-j) & p-value* \\
\hline Day 3 & Day 5 & 2.18 & 0.099 \\
& Day 7 & 4.62 & $0.004^{\star}$ \\
& Control & -1.58 & 0.213 \\
Day 5 & Day 7 & 2.43 & 0.071 \\
& Control & -3.76 & $0.012^{\star}$ \\
Day 7 & Control & -6.20 & $0.001^{\star}$
\end{tabular}

${ }^{*}$ Post-hoc LSD; level of significance $\mathrm{p}<0,05 ; \mathrm{Cl} 95 \%$
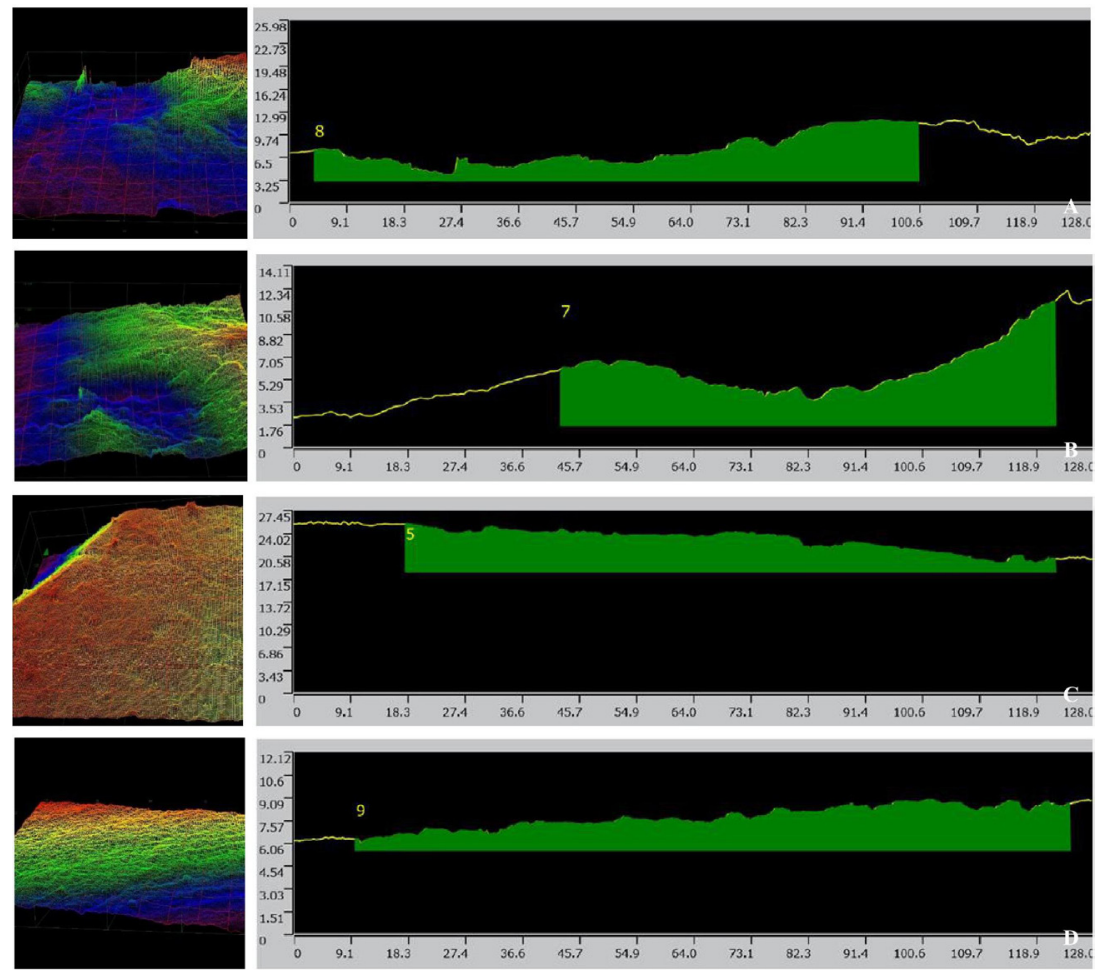

Figure $13 \mathrm{D}$ reproductions of tooth from CLSM data showing representative regions at the interface. (A) 3-day; (B) 5-day; (C) 7-day; and (D) control

in the cavities, lowered the microhardness of tooth structure.

Moreover, the results of tooth surface values after the application of combined extract in evaluated groups showed that there was a gradual figure 1 . Three days period showed flat cavity floor and the larger area of irregularities; 5-day period showed flat cavity floor with more profound irregularities resembling valley; and 7-day period showed flat cavity floor and slight irregularities; while control showed flat cavity floor and lots of porosities.

\section{Discussion}

In Indonesia, the traditional use of plants as medicine for healing have been handed down orally from generation to generation. Some plants are still used in rural areas, and some of them have been made as phytopharmaca available in over the counter. ${ }^{14}$ In dental practice, clove oil, gambir, jatropha, sidaguri and bee venom have been usually used to relieve dental pain by applying them directly to the affected tooth. ${ }^{4-7}$

A preliminary in vitro study in an animal model with periapical lesion showed that the root of sidaguri was able to decrease C-reactive protein level (CRP), one of many molecules that take part in the acute inflammatory process. ${ }^{8}$ Another study showed that root of sidaguri was a non-selective COX inhibitor, an enzyme involved in the synthesis of prostaglandin E2. ${ }^{4}$ These showed that root of sidaguri has analgesic and anti-inflammatory effects. On the other hand, jatropha sap has also been reported to decrease $\mathrm{PGE}_{2}$ in the first 24 hours of its application. However, it caused lysis of pulp blood artery after 24 hours that might devitalize the pulp. ${ }^{10}$

The results of this study showed that changes occurred on the cavities floor after herb application. Tooth structure irregularities were observed in each time of duration, and the longer the duration, the deeper the irregularities. This might be due to the low $\mathrm{pH}$ of jatropha sap ranged 3.3 till 3.6. ${ }^{10} \mathrm{In}$ addition, NMR study showed that extract of root of sidaguri contains carboxylic group which is also acidic. ${ }^{4}$ CLSM images also showed some irregularities on the base of cavities following application of root of sidaguri extract that depended on the doses of extracts. Extracts of $25 \mathrm{mg}$ dose and $50 \mathrm{mg}$ dose of root of sidaguri showed no significant difference (unpublished data.). Therefore, this study was conducted by choosing $25 \mathrm{mg}$ extracts of sidaguri to be combined with Jatropha sap.

Similar to this study, Lestari et al. ${ }^{15}$ found acidic carbonated beverages caused microstructure changes in teeth. Porosities of enamel surface like honeycomb were clearly observed under 1000x magnification using SEM. ${ }^{15}$ However, these results were in contrast to the results reported earlier. Under Scanning Electron Microscope (SEM) evaluation, Mattulada ${ }^{10}$ found that teeth did not show any changes either on enamel or dentin following application of jatropha sap extract. ${ }^{10}$ This might be explained by differences in the duration of tooth immersion. In this study, the samples were immersed in jatropha sap extract for 3, 6 and 24 hours consecutively, while combined extracts of the root of the sidaguri and jatropha sap were applied directly on the floor tooth cavities kept immersed for 3, 5 and 7 days.

The results of tooth microhardness tests confirmed the CLSM studies. It was found that 
the tooth microhardness decreased in each time of combined extracts application, which was significantly lower than control. The porosities formed might enable the combined extracts to diffuse and penetrate through the tooth irregularities that caused massive inflammation to pulp tissue and devitalized the pulp. This is similar to the caries process as localized dissolution of hard tooth structure originated from the complex interaction of cariogenic oral bacteria with fermentable carbohydrates on the tooth surface over time. ${ }^{1}$

This was the first study to examine the mechanism of combined extracts of root of sidaguri and jatropha sap applied in tooth cavities. Studies should be conducted to be further disclosed the exact mechanism. Under the limitations of this study, it can be concluded that combined extracts of root of sidaguri and jatropha sap extracts caused tooth porosities and decreased the microhardness of tooth structure. Based on their effect, it is assumed that a combination of both extracts might have benefits in the devitalizing tooth pulp.

\section{Conclusion}

Combined extracts of root of sidaguri and jatropha sap might have a benefit to be further developed as an alternative as devitalizing agent of the dental pulp.

\section{Acknowledgment}

The authors would like to thank the Ministry of Research, Technology and Higher Education of the Republic of Indonesia for funding this research. The authors gratefully acknowledge Ananda Nurul $\mathrm{F}$ and Aulia Ramli for their support for samples preparation used in these studies.

\section{Conflict of Interest}

The authors report no conflict of interest.

\section{References}

1. Jágr $\mathrm{M}$, Eckhardt $\mathrm{A}$, Pataridis $\mathrm{S}$, et al. Proteomics of human teeth and saliva. Physiol Res 2014;63(Suppl 1): S141-S154.
2. Shashikiran ND, Subba Reddy VV, Hiremath MC. Estimation of trace elements in sound and carious enamel of primary and permanent teeth by atomic absorption spectrophotometry: An in vitro study. Indian J Dent Res 2007;18: 157-162.

3. Anjum A, Otsuki M, Matin K, et al. Preservation in the liquid media produces alterations in enamel surface properties. J Dent 2009;37: 884-890.

4. Tanumihadja M, Mattulada IK, Natsir N, et al. Structural assessment of chemical constituent of sidaguri (Sida rhombifolia Linn.) and its ability to inhibit cyclooxygenase. Pesqui Bras Odontopediatria Clin Integr 2019;19: e4773.

5. Tanumihadja M, Mattulada IK, Natsir N, et al. Potensi kombinasi ekstrak akar sidaguri (Sida rhombifolia L.) dan getah jarak (Jatropha curcas L.) sebagai bahan devitalisasi. ODONTO 2019;6: 14-20.

6. Taher YA, Samud AM, El-Taher FE, et al. Experimental evaluation of anti-inflammatory, antinociceptive and antipyretic activities of clove oil in mice. Libyan J Med 2015;10: e28685.

7. Oswari L, Hidayat R, Fatmawati F, et al. Gambir extract (Uncaria gambir) decreases inflammatory response and increases gastric mucosal integrity in Wistar rats - Model gastritis. Open Access Maced J Med Sci 2019;7: 3149-3152.

8. Tanumihardja M, Natsir N, Mattulada IK, et al. Potent anti-inflammatory effect of root of sidaguri (Sida rhombifolia $\mathrm{L}$ ) on rat periapical lesion model. Int J Toxi Pharm Res 2016;8: 412-415.

9. Tanumihardja $\mathrm{M}$, Natsir $\mathrm{N}$, Mattulada IK, et al. Pharmacological evaluation of ethanol extract of Sida rhombifolia L. roots (Malvaceae). J Chem Pharm Res 2016;8: 770-774.

10. Mattulada I. SEM images of teeth exposed to jatropha sap (Jatropha curcas Linn). J PDGI 2013;62: 72-75.

11. Olley RC, Alhaij S, Mohsen BM, et al. Novel ConfocalLaser-Scanning-Microscopy and conventional measures investigating eroded dentine following dentifrice dab-on and brushing abrasion. Heliyon 2020;6: e03282.

12. Mallya L, Kundabala M, Jathanna V. Confocal LASER scanning microscopy (CLSM) for evaluation of endodontic microflora - A review. Indian J Public Health Res Dev 2019;10: 69-73.

13. Tonini R, Giovarruscio M, Gorni F, et al. In vitro evaluation of antibacterial properties and smear layer removal/ sealer penetration of a novel silver-citrate root canal irrigant. Materials (Basel, Switzerland) 2020;13: e194.

14. Handayani. Traditional to rational and modern phytopharmaca. Proceeding of Surabaya International Health Conference. Surabaya: NU University of Surabaya; 2017.

15. Lestari N, Suryatmojo I, Sembiring L. The effect of consuming carbonated drinks on the erosion of the maxillary permanent incisors. SONDE 2018;3: 48-69. (In Indonesia)

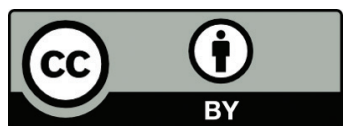

This work is licensed under a Creative Commons Attribution 